This article was downloaded by: [University of Sussex Library]

On: 06 February 2015, At: 05:55

Publisher: Routledge

Informa Ltd Registered in England and Wales Registered Number: 1072954

Registered office: Mortimer House, 37-41 Mortimer Street, London W1T

3J H, UK

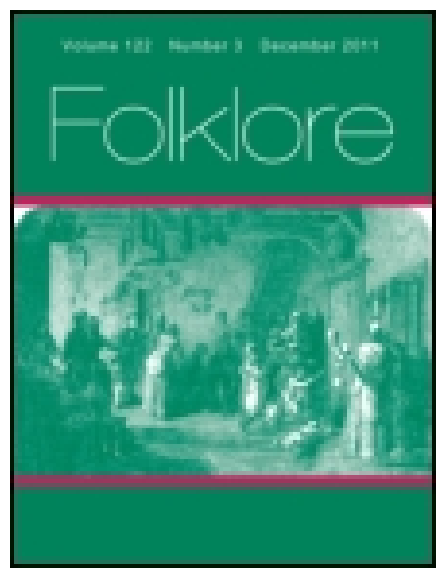

\title{
Folklore
}

Publication details, including instructions for authors and subscription information:

http:// www. tandfonline.com/loi/ rfol20

\section{The Rosary in Magic and Religion.}

Winifred S. Blackman

Published online: 01 Feb 2012.

To cite this article: Winifred S. Blackman (1918) The Rosary in Magic and Religion., Folklore, 29:4, 255-280, DOI: 10.1080/ 0015587X.1918.9719067

To link to this article: http:// dx. doi. org/ 10.1080/0015587X.1918.9719067

\section{PLEASE SCROLL DOWN FOR ARTICLE}

Taylor \& Francis makes every effort to ensure the accuracy of all the information (the "Content") contained in the publications on our platform. However, Taylor \& Francis, our agents, and our licensors make no representations or warranties whatsoever as to the accuracy, completeness, or suitability for any purpose of the Content. Any opinions and views expressed in this publication are the opinions and views of the authors, and are not the views of or endorsed by Taylor \& Francis. The accuracy of the Content should not be relied upon and should be independently verified with primary sources of information. Taylor and Francis shall not be liable for any losses, actions, claims, proceedings, demands, costs, expenses, damages, and other liabilities whatsoever or howsoever caused arising directly or indirectly in connection with, in relation to or arising out of the use of the Content.

This article may be used for research, teaching, and private study purposes. Any substantial or systematic reproduction, redistribution, reselling, loan, sub-licensing, systematic supply, or distribution in any form to anyone is 
expressly forbidden. Terms $\&$ Conditions of access and use can be found at http://www.tandfonline.com/page/terms-and-conditions 


\section{Jfolk $=\mathfrak{T l}$ ore.}

TRANSACTIONS OF THE FOLK-LORE SOCIETY.

Vol. XXIX.] [NCEMBER, 1918.
[No, IV.

THE ROSARY IN MAGIC AND RELIGION.

BY WINIFRED S. BI.ACKMAN.

(Read before the Society, November 20th, I918.)

I Have been recently engaged at the Pitt-Rivers Museum, Oxford, in labelling, cataloguing and arranging a collection of rosaries, a large part of which formed the Tylor collection, presented to the Pitt-Rivers Museum by Sir Edward Tylor shortly before his death. This very interesting piece of work was entrusted to me by the Curator, Mr. Henry Balfour, and I desire to take this opportunity of thanking him, not only for giving me the chance of doing such an instructive and fascinating piece of work, but also for much kindly help and guidance in many ways, amongst others, for reading through the whole of the MS. of my article on Rosaries which I have written for Dr. James Hastings' Encyclopadia of Religion and Ethics. The papes which I have the honour of reading to this Society and my article for the above-mentioned encyclopædia are based on the collection of rosaries at the Pitt-Rivers Museum.

vol. Xxix. $R$ 


\section{The Rosary in Magic and Religion.}

I also wish to express my grateful thanks to Dr. W. Crooke for invaluable help in dealing with the rosaries of India, on which he is so great an authority. A large number of the rosaries included in the Pitt-Rivers Museum were presented by him some years ago.

My thanks are also due to the Rev. H. Thurston, S.J., who has been most kind in checking all my work on Christian rosaries. He moreover supplied me with a number of references in literature, and, what is of greater value still, has given me several of his own learned papers on the subject. I am also indebted to him for the loan of a number of the slides which I propose to show you.

To Dr. Gaster I would express my gratitude for much kindly encouragement in my work and for invaluable help and criticism.

The Rosary is designed as an aid to the memory, and, when used in religious exercises, provides a convenient method for counting the recitation of prayers, or the repetition of the names and attributes of the Deity. It generally consists of a string of knots or beads.

The use of such an instrument is very widely spread, but its earliest home seems to be in Asia, where it can lay claim to a fairly venerable antiquity.

Time will not permit me to discuss at any length the possible origins of the rosary, and indeed I can do no more than put forward suggestions, it being out of the question at this stage to interpret facts with any certainty.

The use of knots as mnemonic signs is almost universal, and such a simple device may have been invented again and again; its appearance in many countries does not necessarily prove that it was invented in one locality and transmitted thence to other centres.

In the quipu of ancient Peru is seen perhaps the highest development of a system of knots as a means of aiding the memory and for keeping records. It was a systern of 
knot-writing, each knot having a separate meaning, the different coloured cords also having each its own signif. cance. ${ }^{1}$ In China in the times of Yung-ching-che, it is stated that the people used little cords marked by different knots, which, by their numbers and distances, served them instead of writing. ${ }^{2}$ In the rosary used by the Shin Gon sect of Buddhists in Japan there is a knot formed by the union of two strings which hang from the main string of beads, and it is said to resemble an ancient Chinese character which means "man," being one of a combination of characters used in representing one of the many attributes of Buddha. ${ }^{3}$

The use of knots as mnemonic signs for purely secular purposes still persists in many countries. In this country it is a common practice to tie a knot in a handkerchief as an aid to memory. The same custom is found in India, the knot being usually tied in the strings of the paejamas (drawers). Such customs are apt to disappear with the advance of culture and the introduction of less cumbrous methods, being retained only for religious purposes. Such a survival of the use of knots for keeping records is seen in some rosaries at the present day in the Greek Orthodox Church, in Egypt, and in India. It will be noted that these rosaries made of knots are highly ceremonial. I shall speak of them later on when dealing with the different religions.

I should like to draw the attention of the Society to an article written by Dr. Gaster in Folklore, vol. xxv., June 3oth, 1914, pp. 254.258, where he suggests that knots provide us with the origin of the rosary beads. I hope to

1 E. B. Tylor, Early Hist. of Mankind (London, 1865), pp. 154.158. See also Marquis de Nadaillac, Pre.Listoric America, pp. 456.458; fig. 202.

A. Y. Goquet, Origime des lois, des ar/s at des stiences (Paris, 1758), vol. i. p. 4.

Joum. Astatic Soc. of Japan, ix. (1881), 177.

AR. C. Temple, Punjabs Notes and Queries, ii. (1885), 571. 
258 . The Rosary in Magic and Religion.

be able to bring forward evidence which certainly seems to corroborate his theory.

Dr. Crooke considers that "the belief in the efficacy of beads is at the basis of the use of rosaries," the value being attached to the material rather than the form. ${ }^{1}$

Notched sticks arealso of universal use for record-keeping, such as the tally-sticks which were utilised in England and Ireland almost up to the present day. In Ireland in quite recent times such sticks have been employed to record the number of prayers uttered, and the suppliant would leave such a stick as a votive offering at some sacred well. Mr. Henry Balfour has called these sticks "votive rosaries."

Age of the Rosary. The oldest reference to rosaries, as far as I have been able to ascertain, is to be found in the literature of India. In the Jaina Canon, composed, I believe, two or three centuries B.c., they are referred to as forming one of the appliances of Brahmanical monks.

References in later literature occur in Brahmanical works only." The following passage from the Buddhist "Forty-two Points of Doctrine," art. 10, alludes to the rosary: "The man who, in the practice of virtue, applies himself to the extirpation of all his vices is like one who is rolling between his fingers the beads of the chaplet. If he continues taking hold of them one by one, he arrives speedily at the end. By extirpating his bad inclinations one by one, a man arrives at perfection." $a$

Distribution. The rosary is found to be in use among Hindus, Buddhists, Muhammadans and Christians. It also has a use among some Jews.

Hindu Rosaries. It is generally considered that the Hindus were the first to evolve the rosary. The Sanskrit name for it is jopr-maila, "muttering chaplet" ; sometimes it is called smarani, "remembrancer," because by - Folk-lore of Northern /ndia, vol. ii. p. 19.

"See E. Leumann, "Rosaries mentioned in Indian Literature," Oriensal Congress Kiep., I891.

(Quoted by Dr. Zetfl, Journ. Sac. of Arts, 1873, F. 469 . 
means of its beads a certain number of prayers, or mantras, may be counted. The operation of thus counting is resorted to by Ascetics to promote contemplation and mental abstraction.

The rosary differs according to the sect to which it belongs, and the number of the beads also varies. Devotees of Siva are supposed to use a rosary of thirty-two beads, or that number doubled; on the other hand, worshippers of Vishnu are said to use one with 108 beads. This rule does not seem to be very strict, as the number 108 is also sometimes found on Saivite rosaries; and indeed the beads may run into several hundred irrespective of the sect. To each rosary there are generally one or more terminal beads which are not usually counted in with those on the main string.

Materials. The materials of which the beads are made play a very important part in Hindu rosaries; they also are of great variety, each having a specific purpose.

A favourite bead of the worshippers of Siva is that known as Rudraksha (" eye of the god Rudra or Siva"). These seeds, according to a Siva legend, are said to be the tears of Rudra (or Siva), which he let fall in a rage (some say in grief, some in ecstasy), and became crystallised into this.form. In the Punjab importance is attached to the number of facets on the seeds. These slits, which run from end to end of each seed, are called "mouths" (munh). A one-mouthed rudraksha affords a very valuable amulet, and, if the owner cannot be induced to part with it, it must be stolen from him and thereafter encased in gold and carefully preserved as a family relic. Such beads can only be obtained from the most accomplished Jogis, and the would-be owner of such a treasure must be prepared to pay any price that is demanded of him. Rudraksha seeds with eleven facets are worn by celibate Jogis, while the married ones wear those with two; the five-faceted seeds being sacred to the monkey god, Hanumän. The five 'W. Crooke, Things Indian, p. 408. 
facets are also sometimes thought to stand for the five faces, or the five distinct aspects of Siva. ${ }^{1}$ The worshippers of Vishnu favour smooth beads, especially those made of the tulasi, or holy basil (Ocimum Sanctum). The Saktas use no beads but count to 100 on the three joints of each finger on the right hand, each ten being marked off on the joint of one of the fingers on the left hand. When they have gone through 100 recitations in this way, they place that number of millet grains before them. This is repeated till the required number is reached. The Atiths of Bengal break up their rosaries into separate parts which serve them as ornaments also. They wear a string of beads from the elbow, a wristlet with five beads, while hanging from each ear is a pendant of three beads. ${ }^{2}$ Among the Jains the laity generally use the rosary when repeating the navakar mantra, to which great sanctity is attached. The materials vary according to the use to which they are put, and the wealth of the owner. The poor Jains generally have to be content with rosaries made of cotton thread and sandal-wood; their richer co-religionists using beads of red coral, crystal, cornelian, emerald, pearl, silver and gold. In this sect there are two special uses of the rosary when rosaries of five different colours are used, viz., red, yellow, green, white and black. They are used on some occasions for the repetition of certain mystical formulae and incantations to appease and propitiate certain deities on special occasions. They are also used for the repetition of mystical formulae, charms, spells, and incantations, with a view to obtaining certain benefits from the deities. They may, moreover, be used for harmful purposes-to injure hostile or obnoxious people, or to disable them, to make them ill, to kill them, to subduc them, to obtain their affections, to make them inert or to summon them. ${ }^{3}$

Monier-Williams, Modern India and the Intians, p. Ito.

W. Crooke, Things ludian, p. 409.

- North Indian Notes and Queries, iii. (1893), 84. 
Among devotees the size of the rosary beads is very important ; the larger they are the more effective is the rosary, and the greater the merit attained by the user of it. ${ }^{1}$

The rosary plays an important part in the initiation ceremony, when children are admitted to the religion of Vishnu at the age of six or seven years. The rosary used on this occasion generally has beads made of tulasi wood. It is passed round the neck of the candidates by the priest (Guru), who teaches them one of the sacred formulae, such as "Homage to the divine son of Vasudeva," "Homage to the adorable Rama," or " Adorable Krishna is my refuge." 2

A high-caste Brahman is careful to conceal his hand in a bag when telling his beads, so that he may not "be seen of men." This bag is called "cow's mouth," gaumukhi. It is often beautifully embroidered and is of a particular shape.

In the monasteries a novice is instructed to be very careful not to lose his beads; should he do so, he is allowed no food or drink till he has recovered them, or, failing this, till the Superior has invested him with another rosary.

Further special uses for the different kinds of beads are as follows: "If a rosary be used in honour of a goddess the beads should be of coral (prival); if in honour of Nirgun Brahma, they should be of pearl (mukta-mala); if with the object of obtaining the fulfilment of wishes (rudsna), they should be of rudrakshas ; ... if with the object of obtaining salvation (moksha), they should be of crystal (spathik); and if with the object of subduing the passions (stambhan), of turmeric roots," 3

The Sikhs have a rosary which consists of knots instead of beads. This is an interesting form of rosary, as possibly it is a survival of an early method of keeping count by a system of knots. It is made of many strands of wool,

\footnotetext{
1 See Monier.Williams, Arodern India and the Indians, p. Ir 3 f.

"Monier. Williams, Religious Thought and Lifo in India, p. 117.

'K. Raghunathfi, Punjab Notes arad Queries, iii. 608.
} 


\section{The Rosary in Magic and Religion.}

knotted together at intervals- 108 knots in all. This kind of rosary is not very durable, the material of which it is made being liable to the ravages of moths. Another kind used by Sikhs is made of iron beads, arranged at: intervals and connected by slender iron links. They have a rosary also which is peculiar to them and is worn like a bracelet on the wrist. It is made of iron and has twentyseven beads. The rosary with this number of beads has a particular name (Lohé kd Simarna), and it forms also a tribal mark. ${ }^{2}$ The Sikhs also have a bracelet rosary with knots instead of beads.

There is a certain number of verses which contain rules about rosaries. Among them are the following ": "The wood of the nim tree, Nagelia putramjiva, conch shell, lotus fruit, and gems, kusa grass and rudraksha, are proper articles to make beads for telling spells (mantra) on. Their efficacy is according to the order in which they are placed; the last one being the best."

"If you tell your mantra on your fingers once you will have the reward for telling your mantra only once, but if you do so on beads of nim wood once, you will have the reward for telling it ten times. If you do so on beads of conch or gems or coral, you will have the reward for telling it a thousand times. If you do so on beads of pearl once, you will have the reward for telling it ten thousand times. If you do so on beads of gold, you will have the reward for telling it a hundred thousand times. If you do so on beads of kusa grass, you will have the reward for telling it a million times; and if you do so on beads of tulsi wood, you will have the reward for telling it innumerable times...."

"Those that are noisy, easily moving, broken, knotty, and strung together on a broken thread are fit to be worn by a hypocrite."

'C. J. N. Bhattacharya, Hindu Castes and Sects, p. 510.

3 Pandit Râmgharfb Chaube, N. Ind. Notes awa' Queries, iil., May, 1893, 57. 
"Rosaries strung on a dirty thread are calculated to bring misery to the persons who use them. . . ."

"The thread of the rosary should not be touched with the forefinger, nor should one shake the hand while telling the beads."

"Putting the rosary on the middle part of the right-hand thumb, move the beads."

"Drawing the beads with the middle finger is calculated to realise the desires of the person who tells the beads."

"One should not draw the beads with other fingers, nor should one touch the beads with the nails."

"In default of rosaries of wood one can use the rosary of kusa knots on the fingers. One should tell the beads in this way with his mind undisturbed and closely attentive."

In order to strike fear into their oppressors Brahmans sometimes keep their hair unshaven and allow their nails to grow to a great length. At the same time they wear about their neck and hold in the hand-usually the right hand-beads of earth on which they tell mantras. It is believed that by so doing they destroy the oppressor root and branch.

Charms. It is sometimes difficult to distinguish between the rosary proper and a charm; indeed the rosary itseif is often a charm. Some of the snake-charmers in India use rosaries made of snake-bones which arc hung on to their musical instruments. The beads of these rosaries are sometimes used as charms to cure snake-bite by tying them on to the wrist of the sick person. ${ }^{2}$ In sume parts of India similar rosaries are used as protective charms by snake. charmers. Fagirs use rosaries made out of the vertebrae of a snake which they carry about to show that they can cure snake-bite. ${ }^{2}$ Such a rosary is sometimes worn tied to the turban, and a special mantra is recited on these

${ }^{1} N$. Int. Notes and Queries, iii. 56.

"W. Crooke, Thing's Indian, p. 408. 


\section{The Rosary in Magic and Religion.}

beads to effect the cure. This is an example of the universal belief in the " doctrine of signatures."

There is a rosary much used by Hindus of the Sakti sect which is called Putr Fiwa ("which gives life to sons "). It is composed of beads made of light-coloured seeds, oval in shape, which grow very plentifully. This rosary is used by a Hindu when he wants a son. No doubt the idea of fertility is involved here.

Another rosary, used by Hindus who wish to get rid of their superfluous flesh, is made of small, almost black seeds, dry and shrivelled-looking, being rather like dried currants in appearance. Doubtless the user of such a rosary hopes that by repeating prayers on it he may obtain a likeness to the seeds, and shrivel up and decrease in size himself.

A rosary from the Partabgarh district ${ }^{1}$ consists of very small beads, plus the terminal, and is finished with a tassel of pink wool. This rosary is stated to be used to prevent the effect of the "evil-eye."

Buddhist. The Buddhist rosary is probably of Brahman origin, and here again the number of beads on the string is usually 108 . This is said to correspond with the number of mental conditions, or sinful inclinations, which are over. come by reciting the beads. Moreover, I08 Brahmans were summoned at Buddha's birth to foretell his destiny. In Burma the footprints of Buddha have sometimes 108 sub-divisions, in Tibet the sacred writings (Kahgyur) run into 108 volumes; in China the white pagoda at Peking is encircled by 108 columns, and in the same country I08 blows form the ordinary punishment for malefactors. Again in Japan, at the bommatsuri or bonku (festival of the dead), observed from I2th to I5th July, 108 welcomefires are lighted on the shores of sea, lake, or river; and 108 rupees are usually given in alms."

Besides the full rosaries of 108 beads, smaller ones are

1 Specimen in Tylor coll. at the Pitt-Rivers Mus.

2'ro. U.S. National Afus., xxxvi. 335 f. 


\section{The Rosary in Magic and Religion. $\quad 265$}

also used, the number of beads representing the chief disciples of Buddha.

India. In India the Buddhist rosaries seem to differ but little from many of those used by Hindus. Some are made of more costly materials than others, the more valuable being of turquoise, coral, amber, silver, pearls, or other gems. The poorer people usually have their rosary beads made of wood, pebbles, berries, or bone, and they are often satisfied with only thirty or forty beads.

Burma. The Burmese rosary again has 108 beads. It seems to be used merely as a means of counting the repetitions of the names of the Buddha trinity, viz. Phra (Buddha), Tara (Dharma) and Sangha. On completing a round of the rosary the central bead is held, and the formula "Anitsa, Dukka, Anatha," "All is transitory, painful, and unreal," is repeated. ${ }^{1}$ The monks sometimes wear a rosary called bodhi, with seventy-two beads. These beads are said to be made of slips of leaf on which charmed words are inscribed. The leaves are rolled into pellets with the aid of lacquer or varnish." A rare and costly rosary which is sometimes found among rich lay devotees has beads made of compressed sweet-scented flowers. The flowers are pressed into hard cakes and then turned on a lathe into beads. They are said to retain their scent for many years. ${ }^{8}$

Tibet. The rosary is an essential part of a Lama's dress, and is also worn by most of the laity of both sexes. It bears the name phreng-ba, "a string of beads," and the act of telling the beads is called $t a n^{\prime} \cdot c^{\prime} e$, which means literally "to purr like a cat," the muttering of the prayers being suggestive of this sound. The rosaries have 108 beads on the main string. The reason given for this number is that it ensures the repetition of a sacred spell soo times, the

'L. A. Waddell, Journ. Asiatir Soc, Bengral, Ixi. 33.

"Gasetteer of Sikkim, p. 282.

'I. A. Waddell, Pro. Asiatic Sor. Bengal, 1892, p. Igo. 
eight extra beads being added for fear of omission or breakage. There are three terminal beads which are called collectively " retaining or seizing beads," dok-'dsin. They symbolise " the Three Holy Ones " of the Buddhist trinity.

The Tibetan rosaries usually have a pair of pendant strings on which are threaded small metal beads or rings. These serve as counters. Sometimes there are four strings attached. Each string usually has a different terminal. The beads on the string which terminates with a dorje (Indra's thunderbolt) register units, those with a bell mark tens of cycles. By means of these counters 10,800 prayers may be counted, but the number uttered depends largely on the leisure and fervour of the devotee. Old women are especially zealous in this respect. In addition to these counter strings various odds and ends often hang from the rosaries, such as metal tooth-picks, tweezers, etc.

The materials of which the beads are made vary according to the sect, the god or goddess addressed, and the wealth of the owner.

Importance is attached to the colour of the rosary, which should correspond with the complexion of the deity worshipped.

One rosary used by Lamas is made of discs cut from a human skull, of ten that of a deceased Lama. These beads are usually divided into groups by four Raksha beads of large size, and the rosary is often passed through another one composed of other beads.

A rosary composed of beads made of the vertebrae of a snake is used by sorcerers for divination and other purposes in their magic art. Usually there are about fifty vertebrae on a string.

The laity use rosaries made of any kind of bead, and they are not tied by rules as to colour. Also the counter strings attached generally end with a dorje, recording only units of cycles, this being sufficient for the bead-telling of the laity. 
In Tibet the rosary is used for other purposes besides that of prayer, sometimes serving as a personal ornament, and also as a means of reckoning sums. ${ }^{2}$ It is also used in divination, the ceremony being performed by the more illiterate people and by the Bon priests. First a short spell is repeated, and then the rosary is breathed upon and a fairly long prayer is recited in which the petitioner begs various religious protectors and guardians that "truth may descend on this lot," that light may descend on it, and "truth and reality appear in it." After the repetition of this prayer, the rosary is taken in the palm and well mixed between the two revolving palms, and the hands clapped thrice. Then, closing his eyes, the devotee seizes a portion of the rosary between the thumb and finger of each hand, and, after opening his eyes, counts the intervening beads from each end in threes. The result depends on whether the remainder is one, two, or three in successive countings.

The Lamas sometimes use their rosaries to drive off evil spirits. A procession is formed once a year, and part of the performance consists in the Lama flourishing his rosary round about to drive away devils from the village. Rosaries are also used to drive away hailstorms."

China. The full Buddhist rosary in China has the usual number of 108 beads, with three dividing beads of a different size and colour. As in other countries, the materials com. posing them vary. There is also a smaller rosary of eighteen beads, corresponding to the eighteen Lohans (chief disciples of Buddha), each bead being sometimes carved into an image of a Lohan. The Chinese name for rosary is su-chu. The ends of the rosary strings are usually passed through

\footnotetext{
'W. W. Rockhill, Kef. U.S. National Mus., 1893, p. 695. C., the Ahacus in China and Japan.

- Gasetteer of Sikkim, pp. $330 \mathrm{f}$.

Sourn. Anthrop. Soc, Bengal, vol, X. (1914), p. is6.

'Rev. Ekai Kawaguchi, Tkree Vears in Tiber, pp. 271-276.
} 
two retaining or terminal beads, one being large and globular in shape, the other small and oval. Sometimes the larger one contains a sacred relic or a charm. ${ }^{1}$

Part of a Chinese official's dress consists of a rosary of 108 beads of large size, with dividing beads. The latter are sometimes made of richly enamelled silver, and the colour varies with the rank of the official, yellow being the highest grade. ${ }^{2}$ These official rosaries are elaborate and sometimes very costly. They are worn only by dignitaries on state occasions. They are not apparently of religious significance.

As a religious instrument the rosary seems to be chiefly used to count the repetitions of set phrases whereby the devotee stores up merit for himself. If these repetitions are performed in temples, the greater the merit of the votary. The rosary is also used as a means of counting prostrations and prayers. The devotee will prostrate himself and strike the ground with his forehead, at the same time muttering a formula. At the end of each prostration and repetition a bead is moved along the rosary string which hangs round his neck. On occasions of sickness or death there is a ceremonial performance with the rosary. The officiant must either be taken from a certain class of Taoist priests, or be a priest of Buddha. On these occasions the priest chants in a monotonous sing-song certain quotations from the sacred books. Count of these repetitions is kept by means of a rosary, and the benefit and merit obtained by them accrue to those who employ the priests and pay them.s

Korea. The Buddhist rosaries of Korea have IIo beads, though, according to the classics, the number is 108 , the two extra beads being large ones-one at the beginning

'Pro. U.S. National Mus., xxxvi, 338.

II am indebted to Mr. Ischii for this information.

J. Doolitule, Social Life of the Chinese, it. $386 \mathrm{f}$.

'Thid. p. $45^{8}$. $\quad$ /hid, p. 387. 
or head of the rosary usually containing a swastika, the other dividing the rosary into two parts. Each of these beads is dedicated to a deity, and every bead on the string has its own special name. On laying aside the rosary the following sentences should be repeated:

"Oh; the thousand myriad miles of emptiness, the place which is in the midst of the tens of hundred myriads of emptinesses, eternal desert where the true Buddha exists. There is eternal existence with Tranquil Peace."

There is also a small rosary which, if used every day in the four positions or states, viz. going forth and remaining at home, sitting or lying down, enables the votary to see the land of Bliss in his own heart. "Amita will be his Guardian and Protector, and in whatever country he goes he will find a home." 1

Fapan. It is in Japan that the Buddhist rosary reaches its most complicated form, and each sect has its own special rosary. There is, however, one which is used by all sects in common, and is called the Sho-zuku-jiu-dzu. This rosary is also usually carried by monks and laity of all sects, on all occasions of religious state, on visits of ceremony, at funerals, etc. The dividing beads on the main string show where a special invocation should be uttered, the rosary being, at the same time, raised to the forehead with a reverence.

The Jödo sect uses a rosary which consists of two rings of beads, like two bracelets, one being passed through the other. The invention of this rosary is ascribed to Awanosuka, who was one of the personal attendants of the founder of this sect. The idea was that such a rosary could be manipulated with one hand (the left) only, thus leaving the right hand of the attendant free for serving his superior and carrying out his orders. By this means the faithful retainer could combine both his spiritual and secular duties.

The rosary plays an important part in certain ceremonies

I See E. B. Landis, The Korean Repository, vol. ii. No. H. Jan., 1895. 


\section{The Rosary in Magic and Religion.}

performed for special purposes. One of these ceremonies is held for the purpose of curing and preventing disease, and also for dispelling evil spirits. In one of these rites only monks who have undergone a special training may officiate. The monks are trained at a celebrated monastery of the Nicheren sect in Shinöia. ${ }^{1}$

According to one authority, the rosary in Japan plays an important part in the social as well as in the religious life of the people. In the tea-room there is always a hook on which to hang a rosary, and one of value, historical or otherwise, is much appreciated as an ornament for this room. It is said that rosaries were carried by all the soldiers in the Russo. Japanese war. The dead also have a rosary slipped on the wrist, whether they are buried or cremated.

A rosary that has been consecrated over the sacred flame and incense of a venerated temple acquires special value for the devout.

Muhammadan. The rosary used by the followers of Islam generally consists of ninety-nine beads with a terminal bcad called the Jmam, "leader." It chief use is for counting the recital of the ninety-nine names of God, the Imaim being sometimes used for the essential name, Alläl. This rosary is divided into three parts, thirty-three beads in each, by beads of another material or shape, or by tassels which are often mado of gold thread or of bright coloured silks. A smaller rosary of thirty-three beads is very commonly used, and the devotee will go round this three times to get the full repetition of the ninety-nine names. At the present day the rosary is used chiefly by the older or more devout Mubammadans; among the younger peoplo it is tending to become merely something to hold in the hand and finger during leisure hours.

\footnotetext{
For a detalled account of Buddhlst rosaries in Japan, see J. M. James, Journ. Ariatic Sor. Japan, ix. 172-182.

Pro. U.S. National Afus., xxyyi. 347.
} 
Tradition says that the Prophet attributed great merit to those who recited the names of God and repeated certain formulae. "Verily," he says, "there are ninety-nine names of God, and whoever recites them shall enter into Paradise," and, "whoever recites this sentence [the tasbih, "I extol the holiness of God," and the tahmid, "God be praised"] a hundred times, morning and evening, will have all his sins forgiven." 1 At another time the Prophet promises, as a reward for the repetition of a sacred formula, that the devotee "shall receive rewards equal to the emancipation of ten slaves, and shall have one hundred good deeds recorded to his account, and one hundred of his sins shall be blotted out, and the words shall be a protection from the devil." 2

The date of the introduction of the rosary among $\mathrm{Mu}$ hammadans is uncertain. It has been of ten assumed that it was taken over by them in a fully developed form from Buddhism. But tradition and various passsages in the early literature point to a primitive form of rosary, such as would not have been used if borrowed from a people who had it already in a highly developed form.

Muhammadan tradition points to a very early use of the rosary, dating it back even to the time of the Prophet himself. In support of this belief it is related that $\mathrm{Mu}$ hammad reproached some women for using pebbles in repeating the tasbih, etc., suggesting that they should rather count them on their fingers. ${ }^{8}$ Another tradition, collected in the ninth century A.D., relates that $\mathrm{Abu}$ Abd al Rahman, on visiting a mosque and seeing some of the worshippers engaged under a leader in the recitation of 100 takbir, 100 takhlil, and 100 tasbih, keeping count of these by means of pebbles, reproached them and said: "Rather count your sins and I shall guarantee that nothing

'Pro. U.S., National MJus., xxxvi. 348.

"Ilughes' Dic. of Islam, p. 625, s,v. "Tahlil."

"Mro. U.S. National Mus., xxxvi, 349. 


\section{$277^{2}$ The Rosary in Magic and Religion.}

of your good works will be lost." 1 These two examples seem to show that a primitive form of rosary was in use at this time-the "beads" being merely pebbles, apparently unstrung.

The materials of which the rosaries are made are numerous, though each sect tends to have its own specially sacred form of bead. The Wahhabis use their fingers, on which they count their repetitions. ${ }^{2}$ Wooden beads are used by all sects, and beads made of clay from Mecca are highly valued. Pilgrims from this sacred city sometimes bring such rosaries back with them. ${ }^{3}$ Datestones are also much used, as are also horn and imitation pearls and coral. Beads made of earth from Kerbala, where Husain is buried, are sacred to the Shiahs, and are used by members of this sect only. These beads are believed to turn red on the ninth day of Muharram, the night on which Husain was killed. Some of the rosaries have as a terminal a com. plicated knot, usually made of bright-coloured silks; this knot is of a form characteristic of Muhammadan rosaries. Another material of ten used is camel bone. Sometimes beads of this material are dyed red in honour of Husain, who was killed in his conflict with Yazid, the seventh Khalifah, the red colour representing his blood. Sometimes the beads are dyed green, this being Hasan's colour. Hasan, Husain's elder brother, met his death by poisoning. The poison turned his body green after death, henco these beads are in memory of his tragic end." Faqirs, on the other hand, prefer glass beads of various colours, and also amber or agate.

In Egypt, on the first night after a burial, certain

1II. Thurston, Journ. Sor, Arts, 1. 265.

- A.o. U.S. National Mks., xxxvi. 349.

E. W. Lane, Modern Egryptians, p. 444.

- This information was glven me by Mr. Vusuf Khan of Queen's College, Oxiord.

W. Crooke, Things Indian, p. 4 to. 
ceremonies take place at the house of the deceased, among them being that of the subhah, or rosary. After nightfall a certain number of fikees, sometimes as many as fifty, assemble, one of them bringing a large rosary of rooo beads, each bead being about the size of a pigeon's egg. Certain passages from the Qur'ann are recited, after which the formula "There is no Deity but God" is repeated 3000 times. Count of these repetitions is kept by one of the fikees by means of the rosary. Certain other sentences are recited after this, and then one of the officiants asks his companions, "Have ye transferred [the merit of] what ye have recited to the soul of the deceased?" They reply, "We have transferred it," and add, " and peace be on the Apostles, and praise be to God, the Lord of all creatures." This ends the ceremony of the subhah, which is repeated on the second and third nights if the family can afford it. ${ }^{1}$

A further interest is attached to this ceremony in Upper Egypt, because a primitive form of rosary is often used on this occasion. A fikee will bring a plain cord with him, and, as he recites each formula or passage from the Qur'ann, he makes a knot in his cord till he has reached tooo. The merit in this case also is conveyed to the deceased. The cord with its knots is afterwards thrown away.

The rosary is also used in Egypt in what is called making an istikharah, "application for the favour of Heaven, or for direction in the right course." Lane " describes it as follows: The performers take hold of any two points of a rosary; after reciting the Fat'hah (first chapter of the Qur'an) three times, he counts the beads between these two points, saying, as he passes the first bead through his

'Lana, Modern Egytiaws, pp. 331\%. This cexemony is performed to facill. tate tho entranoe of the deceased into atate of happiness. Lane says that it usualiy occuples three or four hours.

I am indebted to Mr. and Mrs. Manzaluoui and Mr. Alam for this information.

- Modern Esyptians, p. 270. 


\section{The Rosary in Magic and Religion.}

fingers, "[I extol] the perfection of God"; in passing the second, "Praise be to God" ; in passing the third, "There is no Deity but God," repeating these formulae in the same order to the last bead. Should the first formula fall to the last bead, the answer is affirmative and favourable; if to the second, indifferent; but if to the last it is negative.

Christian. The introduction of the rosary among Christians has been attributed to various people, among them being St. Aybert de Crespin, Peter the Hermit, and St. Dominic. There has been a fairly widely accepted theory that the rosary was introduced into Europe at the time of the Crusades, having been imitated from $\mathrm{Mu}$. hammadans. But later research seems to show that, though it is possible that such a means of counting prayers may have become more popular at this period, an earlier date should be assigned for its use in Western Europe. It is stated by William of Malmesbury ${ }^{1}$ that the Lady Godiva of Coventry, wife of Count Leofric, bequeathed to the monastery which she founded "a circlet of gems which she had threaded on a string, in order that by fingering them one by one as she successively recited her prayers she might not fall short of the exact number." Lady Godiva died before I070, so that some minemonic device seems to have been in use prior to the preaching of the Crusades. The case of the Egyptian abbot, Paul, who died in 341 , is related by Sozomen (c. 400-450) in his Ecclesiastical History, where it is stated that the saint daily recited 300 prayers, keeping count by means of pebbles in his cloak, dropping one of them at the end of each prayer. Here is a much earlier and more primitive method of record-keeping, which looks as if the rosary may have evolved independently in some centres, and had not been taken over from others in an already developed form.

By the thirteenth century the making of paternosters,

$$
\text { ' Gessa Pontificum (Rollk series), bk, iv. ch. is. 'Bk. vi. ch. } 29 .
$$


as the beads were then called, had become a specialised industry both in Paris and in London.

It has been suggested that the rosary probably arose from a practice in early Christian times of making repeated genuflexions and prostrations, sometimes combined with prayers or sacred formulae. ${ }^{1}$ This form of self-discipline was practised in Eastern Europe and in Ireland, spreading from these two widely separated centres, over the greater part of Europe. Such a form of asceticism survives in the Greek Church at the present day.

Roman Catholic. The full Dominican rosary numbers $I 50$ beads, these being divided into sets of ten by fifteen larger beads. These beads form the chaplet. A pendant, consisting of a cross or crucifix and one large and three smaller beads, is usually attached. The number I 50 corresponds with the number of the Psalms, and this number of paternosters was recited by monks whose education was not sufficient to enable them to learn the Latin Psalms. This would explain how the strings of beads used for thus keeping count came to be called "Paternosters."

The name "Rosary," now given to this devotion, seems to be of comparatively late date-according to one authority not appearing till the fifteenth century. The following charming story is told to explain the origin of this name, though, as Father Thurston has pointed out, the story is older than' the name it professes to explain. The legend occurs in many of the collections of the "Miracles of Our Lady," which were very popular in the Middle Ages. I give it in Father Thurston's own words : "A youth was accus. tomed to make a wreath of roses or other flowers every day, and to place it upon the head of Our Lady's statue. He became a monk, and in the cloister his occupation no longer permitted him to observe this pious practice. Being

'II. Thurston, "Genuflexions and Aves : a Study in Rosary Origins," The Mtonth, cxxvii. (1916), 44 I f, $546 \mathrm{f}$.

"Yourn. Soc. Arts, Feb. 31st, 1902, pl, 2716. 


\section{The Rosary in Magic and Religion.}

much distressed, he asked counsel of an aged priest, who advised him to say fifty Aves every evening (in same versions it is I5O, in others twenty-five), which would be accepted by Our Lady in lieu of the garland. This the young man faithfully observed, until one day, being upon a journey, he has to pass through a lonely wood where robbers were lying in wait. They were employed in watching him, feeling sure of their prey, when he, unsuspicious of their presence, remembered that his Aves were not yet said, and forthwith stopped to say them. Then to their surprise, the robbers saw a most glorious lady stand before him and take one after another from the lips of the kneeling monk, fifty beautiful roses, which she wove into a garland and placed upon her head. The robbers, so the legend tells, conscience-stricken at the vision, were all converted to a better life, and themselves soon after entered the monastery."

The word 'bead' (Anglo-Saxon beade or bede) meant originally 'a prayer.' In the Vision of Piers Plowman the expression "bedes byddyng" is found. Again in Spenser's Faerie Queen we read:

"All night she spent in bidding of her bedes

And all day long in doing good and godly deeds."

The expression "a pair of beads," sometimes met with in early literature, means " a set of beads." We find this term used in the Prologue of Chaucer's Canterbury Tales, where the Prioress carries her beads upon her arm:

"Of smal coral aboute hir arm she bar

A peire of bedes, gauded al with grene;

And ther-on heng a broche of gold ful shene,

On which ther was first write a crowned $A$,

And after, Amor vincit omnia."

Ladies sometimes wore these beads as a girdle. In some of the early representations of prayer-beads on tombs the rosary is exhibited not as a circle, but, especially in 
the case of men, as a single string, with the two ends unattached and hanging free. Occasionally these two ends are attached at two different points of a girdle. This form is also seen in some old pictures. ${ }^{1}$

The materials composing the beads varied, and still vary, very much, often depending, as is the case among other religions, on the rank and wealth of the devotee. Chaplets of wood were used at funerals by poor bedesmen, and in 145 I Lord John Scrope wills that "twenty-four poor men clothed in white gowns and hoods, each of them having a new set of wooden beads," should pray (on them) for him at his funeral, with the liberty to "stand, sit, or kneel " at their pleasure."

The Rosary as a Charm. I now give an example of what might perhaps be called a magico-religious use of the rosary. In certain parts of Poland, namely in the districts of Piotrkow, Czestochowa and Plock, the following custom is in use to keep off lightning.

During a storm a rosary with beads of cedar-wood from the Holy Land-or one made in imitation-is carried round the house three times, together with a little bell called "the bell of Loreto," and sometimes also a lighted candle, blessed on Candlemas Day. The bell is rung, and the rosary is used with the words "God save us" at the large beads and "Holy Mother, be our mediator" at the small ones. ${ }^{3}$

Orthodox Churches. In Greek and Slavic monasteries part of the investiture of the Little Habit and the Great Habit is a rosary in the form of a knotted cord which is bestowed ceremonially upon the monk or nun. The knotted cord, as I have already pointed out, is possibly a very primitive form of rosary, and, in this case, it is seen surviving in a highly ceremonial function.

1 Cf. Feasey, The Religuiary, vol. v., No. 3, p. 167.

J6id. p. 173 .

I am indebted to Miss Czaplicka for this information. 


\section{The Rosary in Magic and Religion.}

The Greeks call the knotted cord a komvoschinion

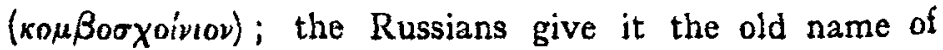
vervitsa ('string'). In popular language it bears the name lestovka because of its resemblance to a ladder (lestnitsa). ${ }^{1}$ There is also a string of beads called komvo-

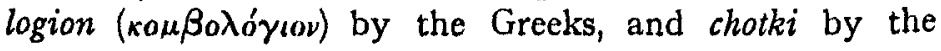
Russians, This, according to one authority, is not a religious appliance, but is used by ecclesiastics and laity merely as an ornament or as something to hold in the hand. ${ }^{2}$

The komvoschinion, as used by monks on Mount Athos at the present day, has Ioo knots, divided by three beads of large size into four equal parts. It has a pendant with three more knots, and terminates with a small cross-shaped tassel. This rosary is used by monks of the highest grade to keep count of a definite number of prostrations every day, a prayer being repeated at the same time. These prostrations are sometimes imposed on a monk as a penance. The komvoschinion is also used for counting any kind of prayers or devotional exercises. ${ }^{8}$

This form of komvoschinion is used by Hellenic monks in Greece, Turkey, and the East generally, as well as on Mount Athos.

Among the Russian monks the knotted cord used by them is the old Slavic vervitsa. It has I03 knots or beads, separated into unequal groups by larger beads. The groups are arranged as follows: $17+33+40+12$, and an additional small bead at the end. In the Slavic vervitsa the lower ends are fastened together; they terminate in three flat triangles, inscribed and ornamented. Sometimes these rosaries are made of little rolls of leather chainstitched together, being divided by larger rolls. The

'N. F. Rolsinson, Monasticism in the Urthatox Churches, p. 159 S.

1bid. p. 755 . Father Thurston, however, doubts whet her this clear distinction is justified by usage.

Ibid. p. 155. 
terminals are inscribed in Church Slavic (ancient Slavic) with the words "Jesus Christ, have mercy upon me, a sinner." This kind of rosary calls to mind the popular name for it, viz. lestovka, as it certainly might be thought to resemble a ladder in shape. This rosary is also used for counting a number of prostrations. The vervitsa is a purely monastic or ascetic devotion; it is not indulged in by the Orthodox laity, though the laity of the Russian sects, called "Old Believers," have adopted it.

Coptic. The rosaries used by the Copts of Egypt have forty-one, or sometimes sixty-one, beads. They are used for counting a similar number of repetitions of the "Kyrie eleison." This petition is repeated in Arabic or Coptic, with the addition, at the end, of a short prayer in Coptic. Sometimes the Copts resort to what is, presumably, a more primitive method of keeping record of their prayers, and count on their fingers. ${ }^{1}$

Fewish. It now remains to mention the use of the rosary by the Jews. Among these people it has lost all religious importance, having been taken over by them from the Turks and Greeks. They use it merely as a pastime on the Sabbaths and holy days. No manual labour being permitted on those days, they occupy them. selves with passing the beads through their fingers. These rosaries sometimes have thirty-two beads, sometimes ninety-nine. Dr. Gaster has suggested to me that there may be a cabalistic reason for the number thirty-two. It is the mystical number for the "ways of wisdom" by which God created the world. They stand at the beginning of the so-called Book of Creation, and they play an important rôle in the cabalistic literature. It may be that this has infuenced the number of beads on the smaller rosaries.

I desire to thank the Society for giving me this oppor-, tunity of speaking on a subject which I have found most

${ }^{1}$ Lane, Moulern Egrptians, p. 54 '. 


\section{The Rosary in Magic and Religion.}

interesting myself, and I trust that the material I have collected may be of some use to others. I conclude this paper with the hope that no one will quote against my array of very miscellaneous facts a proverb from Assam which protests against a love of futile display in the words : "There are many rosaries, the beads of which are not told in devotion." 1

1 Some Assamese Proterbs, compiled and annotated by Captain P. R. Gurdon, I.S.C. Quoted in a review of the book in Journ. Roy. Asiatic Soc., vol. xxviii. p. 809 . 